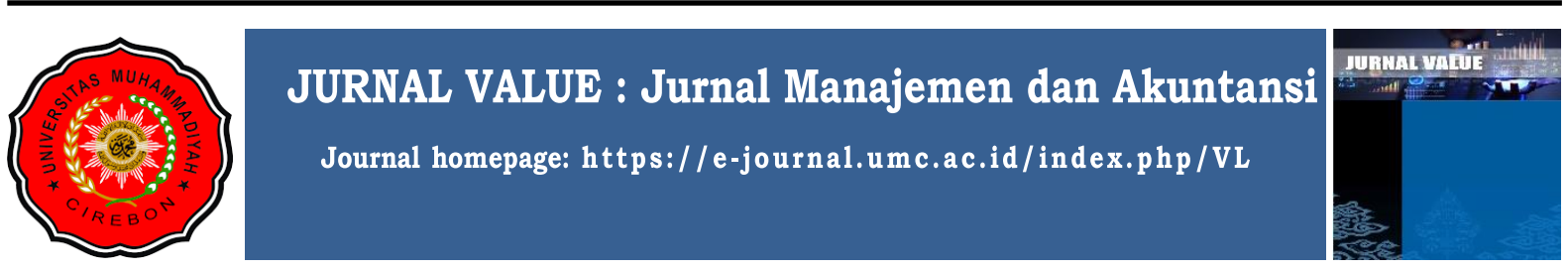

\title{
COACHING DAN KINERJA INDIVIDU: ANALISIS MEDIASI KOMITMEN KERJA PADA KARYAWAN INDUSTRI MANUFAKTUR
}

\author{
Bonar Bangun Jeppri Napitupulu \\ Sekolah Tinggi Ilmu Ekonomi Insan Pembangunan, Tangerang, Indonesia \\ Email:bonama70.ip@gmail.com
}

Diterima : 6 Juli 2021

Direvisi : 11 Juli 2021

Dipublikasikan : 3 Agustus 2021

\begin{abstract}
Asbtrak
Studi ini menyelidiki apakah peningkatan perhatian yang diberikan pada praktik coaching mempengaruhi kinerja, sambil mempertimbangkan efek mediasi dari komitmen kerja. Data dikumpulkan dari 1019 karyawan salah satu industri manufaktur swasta di Jawa Barat dengan menggunakan metode kuantitatif dan survei konfirmasi dengan bantuan software SmartPLS. Studi ini menunjukkan bahwa praktik coaching memberikan pengaruh positif dan signifikan terhadap kinerja karyawan, baik secra langsung maupun tidak langsung melalui mediasi komitmen kerja. Hasil penelitian ini dapat memiliki implikasi yang signifikan terhadap pengambilan keputusan manajerial SDM tentang proses praktik coaching di lingkungan karyawan industri manufaktur di Indonesia, Studi ini juga membantu manajemen SDM industri manufaktur untuk serius menilai rencana investasi pengembangan SDM dalam bentuk praktik coaching dan mengarahkan perencanaan strategi SDM perusahaan mereka.
\end{abstract}

Kata kunci: Coaching, kinerja, komitmen kerja.

\section{PENDAHULUAN}

Mengingat lingkungan global yang kompetitif di mana organisasi beroperasi, kebutuhan untuk mengembangkan (dan mempertahankan) karyawan yang sangat terampil sangat penting untuk keberhasilan dan kelangsungan hidup organisasi (Asbari, Purba, et al., 2021b, 2021a). Manajemen kinerja secara luas dianjurkan sebagai cara untuk mengembangkan karyawan (Admiral et al., 2021; Asbari, Novitasari, et al., 2021; Fikri et al., 2021; Hutagalung et al., 2021; Novitasari, Asbari, Hutagalung, et al., 2021; Novitasari, Asbari, Putra, et al., 2021; Novitasari, Hutagalung, Amri, Nadeak, et al., 2021; Novitasari, Hutagalung, Silitonga, Johan, et al., 2021; Novitasari, Supiana, Supriatna, Fikri, et al., 2021; Pramono et al., 2021). Secara garis besar, manajemen kinerja dapat didefinisikan sebagai "mengidentifikasi, mengukur, dan mengembangkan kinerja individu dan tim serta menyelaraskan kinerja dengan tujuan strategis organisasi" (Aguinis, 2019). Definisi sederhana ini menggarisbawahi keselarasan yang erat antara praktik manajemen kinerja dan Pengembangan Sumber Daya Manusia (SDM). Meningkatnya tekanan dan persaingan, menjadikan tugas mengelola sumber daya manusia secara efektif telah menjadi faktor kunci keberhasilan bagi perusahaan mana pun. Dengan demikian, perusahaan secara permanen berusaha meningkatkan keunggulan kompetitif mereka terutama melalui sumber daya manusia. Praktik manajemen sumber daya manusia (MSDM), di antaranya coaching, training, seleksi, penghargaan dan partisipasi memainkan peran penting dalam mengembangkan keterampilan karyawan dan karenanya meningkatkan kinerja 
organisasi. Dengan menerapkan prosedur rekrutmen dan seleksi yang baik, perusahaan akan menarik banyak karyawan berbakat yang keterampilannya akan lebih meningkat melalui training dan coaching yang ekstensif. Selain itu, jika dilibatkan secara tepat dalam proses pengambilan keputusan, karyawan tersebut akan termotivasi dan terdorong untuk bekerja lebih keras yang pada akhirnya mendorong kinerja perusahaan. Coaching adalah salah satu teknik dalam pengembangan sumber daya manusia (SDM) yang dapat membantu perusahaan menciptakan keunggulan kompetitif. Saat ini, semakin banyak organisasi bisnis yang menggunakan coaching untuk pemberdayaan karyawannya, karena dengan coaching dapat menyelesaikan beberapa masalah di tempat dan juga efektif dalam meningkatkan kinerja yang buruk. Selain itu, coaching adalah alat pembelajaran karier dan dapat dianggap sebagai kesempatan untuk belajar, serta dapat digunakan untuk memastikan kepemimpinan yang berkelanjutan. Namun, meskipun coaching menjadi semakin populer dengan banyak praktisi yang mengklaim pentingnya dalam meningkatkan kinerja, literatur menawarkan sedikit bukti empiris mengenai efek dari praktik ini terhadap kinerja dan juga bagaimana cara kerjanya.

Kesenjangan literatur selanjutnya disorot oleh Grover \& Furnham (2016) yang menekankan program evaluasi coaching terbatas pada level yang dilaksanakan oleh organisasi. Selain itu, dalam penelitian terbaru yang meneliti pengaruh coaching terhadap kinerja karyawan, Sidhu \& Nizam (2020) menjelaskan bahwa meskipun coaching secara umum tercakup dengan baik oleh literatur, namun masih ada kebutuhan untuk menyelidiki lebih lanjut faktor-faktor mediasi coaching yang mempengaruhi kinerja, jenis coaching yang diadopsi oleh organisasi serta hubungan antara coach dan coacheenya. Dengan demikian, ada kebutuhan untuk mengeksplorasi proses ini dan pengaruhnya secara empiris. Kesenjangan dalam bukti empiris ini memberikan resiko pada nilai investasi, waktu dan uang dalam praktik semacam itu. Membenarkan efek coaching pada kinerja membantu manajer sumber daya manusia untuk mempertahankan penggunaan praktik ini. Selain itu, literatur sebelumnya masih perlu untuk mengeksplorasi proses melalui mana coaching manajerial membawa hasil yang positif (Asbari \& Prasetya, 2021; Novitasari, Asbari, Hutagalung, et al., 2021; Novitasari \& Asbari, 2021). Coaching yang dipraktikkan dalam organisasi didasarkan pada psikologi perilaku dan kognitif. Coaching bertujuan untuk mengubah perilaku karyawan melalui perubahan kognitif dan motivasi. Karena itu, mempelajari perubahan internal karyawan, terkait dengan peningkatan kinerja, sangat penting dalam rangka untuk memahami mekanisme efektivitas coaching. Pemahaman yang lebih baik tentang proses coaching dapat membantu manajer dan organisasi untuk memanfaatkan coaching secara lebih efektif. Studi ini tidak hanya melihat dampak coaching terhadap kinerja; itu juga mencoba untuk mengurai perubahan internal pada karyawan yang dihasilkan dari porses coaching seperti komitmen kerja dan selanjutnya mempelajari efek dari coaching dan komitmen kerja tersebut terhadap kinerja. Sebaliknya, fungsi SDM di lingkungan organisasi perusahaan masih dalam tahap awal, dimana perannya difokuskan pada administrasi kekaryawanan daripada masalah strategis. Mengetahui bahwa coaching memberikan efek langsung pada kinerja baik level organisasi maupun individu di banyak negara Eropa dan Amerika, tapi masih terdapat kelangkaan studi yang menyelidiki dampak praktik coaching dan komitmen kerja terhadap kinerja karyawan di lingkungan industri manufaktur di Indonesia.

Dengan demikian, studi ini akan membantu menjembatani kesenjangan dalam kerangka teoritis yang menunjukkan dampak coaching terhadap kinerja dan membenarkan penggunaan coaching sebagai bagian dari HRD. Mengetahui bahwa studi itu langka, ada kebutuhan untuk memupuk pengetahuan kita tentang efek coaching pada kinerja dalam konteks industri manufaktur di Indonesia. Dengan demikian, tujuan dari penelitian ini adalah untuk menunjukkan pengaruh coaching terhadap kinerja, baik langsung maupun tidak langusng melalui mediasi komitmen kerja.

Berkenaan dengan implikasi praktis, penelitian ini menawarkan panduan berharga untuk membantu manajer sumber daya manusia pada industri manufaktur di Indonesia untuk bisa menilai keinginan berinvestasi dalam coaching dan mengarahkan perencanaan strategis SDM organisasi mereka. Pada bagian berikut, literatur disurvei dan hipotesis diajukan, diikuti dengan deskripsi metode yang diterapkan. Para peneliti kemudian memposisikan temuan penelitian ini terhadap pengetahuan yang ada di bidang ini untuk menunjukkan bagaimana kita memajukan pemahaman dan praktik coaching di sebuah organisasi industri manufaktur. 


\section{STUDI LITERATUR DAN PENGEMBANGAN HIPOTESIS}

Dalam dua dekade terakhir, praktik coaching dalam organisasi telah mendapat banyak perhatian sebagai alat pengembangan dan manajemen karyawan yang penting (Hunt \& Weintraub, 2016; Sidhu \& Nizam, 2020). Coaching secara luas didefinisikan sebagai hubungan kerja sama antara seorang coach dan coachee-nya (Hamlin et al., 2009). Coaching merupakan praktik sistematis yang membantu dalam perkembangan dan pertumbuhan orang yang kemampuannya sedang dibina oleh seorang coach professional (Hamlin et al., 2009). Banyak peneliti melangkah lebih jauh dalam memeriksa hasil coaching dan variabel yang mengarah pada peningkatan performa karyawan. Berbagai penelitian yang mengidentifikasi hubungan positif antara peningkatan kinerja individu sebagai hasil dari praktik coaching dan kinerja organisasi menggunakan produktivitas untuk mengukur kinerja organisasi (Szabó et al., 2019). Coaching meningkatkan kinerja karyawan dengan meningkatkan hubungan antara coach dan coachee, dan meningkatkan kepuasan, keterlibatan, dan retensi karyawan (Lee et al., 2019). Selain itu, coaching terbukti menjadi alat peningkatan pembelajara (Maamari et al., 2021) yang mengarah pada perubahan perilaku dan memungkinkan karyawan menjadi lebih efisien dan berkinerja lebih baik (Maamari et al., 2021). Studi menunjukkan bahwa coaching merupakan alat yang mampu menciptakan nilai (Asbari \& Prasetya, 2021), yang pada akhirnya meningkatkan kapabilitas sumber daya manusia. Coaching mengubah sumber daya manusia menjadi aset yang unik dan berharga bagi organisasi dan sulit ditiru oleh pesaing. Sebagaimana disebutkan oleh Asbari \& Prasetya (2021), seorang coachee akan menerapkan pengetahuan baru mereka -yang diperoleh dari proses coaching dari seorang coach professional- pada tugas sehari-hari di tempat kerja mereka, yang berdampak positif pada kinerja individu mereka. Dalam kasus lain, Aldrin \& Utama (2019) melakukan pemeriksaan efek coaching pada kinerja kerja tim dan mengidentifikasi korelasi positif antara variabel. Hasilnya coaching mampu mengembangkan dan memperkuat hubungan di antara anggota tim. Coaching meningkatkan kohesi kelompok, mendorong transparansi dan meningkatkan komunikasi kelompok yang pada akhirnya akan meningkatkan kinerja karyawan dan organisasi. Oleh karena itu, organisasi harus terus menerapkan praktik pengembangan SDM baru untuk mendorong komitmen karyawan dan karena itu meningkatkan kompetensi karyawan di tempat kerja (Hsu et al., 2019). Berikut ini, penulis akan mensurvei pengaruh coaching terhadap komitmen tim dan kinerja individu karyawan, sekaligus mengukur sejauh mana pengaruh mediasi komitmen tim mampu meningkatkan hubungan antara coaching dan kinerja individu.

\section{Pengaruh Coaching terhadap Komitmen Kerja}

Studi ilmiah melaporkan hubungan tidak langsung antara coaching dan organisasi komitmen (Hsu et al., 2019; Park, 2007), di mana coaching diperkuat komitmen kerja karyawan (Maamari et al., 2021). Dalam hal ini, coaching dilaporkan mampu meningkatkan komitmen, kemampuan, dan sikap karyawan. Coaching juga mampu meningkatkan kemandirian dan kepercayaan karyawan, dan meningkatkan perasaan kontrol dan pekerjaan identifikasi yang memperkuat komitmen karyawan terhadap organisasi. Selain itu, Asbari \& Prasetya (2021) menyoroti kemampuan coaching dalam meningkatkan rasa memiliki mereka, yang memperkuat komitmen. Dalam kebanyakan kasus, karyawan mengakui bahwa usaha dan biaya yang dikeluarkan oleh perusahaan merupakan upaya untuk mengembangkan keterampilan mereka. Dengan demikian, praktik coaching meningkatkan loyalitas dan komitmen karyawan (Asbari \& Prasetya, 2021; Hsu et al., 2019). Aldrin \& Utama (2019) menjelaskan bahwa efektivitas kecocokan coach dipengaruhi oleh proses coaching, yang menghasilkan rasa saling percaya, percaya diri, kolaborasi dan komitmen. Oleh karena itu, kemitraan ini meningkatkan dedikasi dan komitmen terhadap keberhasilan organisasi. Maamari et al. (2021) menambahkan bahwa karyawan lebih berkomitmen ketika mereka menyadari tentang upaya organisasi dalam mengimplementasikan coaching sebagai bagian dari investasi sumber daya manusia. Oleh karena itu, hipotesis pertama penelitian ini adalah: H1: Coaching meningkatkan komitmen kerja karyawan 


\section{Pengaruh Komitmen kerja terhadap Employee Performance}

Pengaruh komitmen karyawan terhadap kinerja telah dibahas dalam banyak literatur SDM (Asbari et al., 2019; Cahyono et al., 2020; Chidir et al., 2020; Imelda et al., 2020; Kusumaningsih et al., 2020; Novitasari et al., 2020; Purwanto et al., 2021; Silitonga et al., 2020; Yuwono, Novitasari, Asbari, et al., 2020). Menurut Chidir et al. (2020), manajer berusaha meningkatkan kinerja dengan memperkuat komitmen karyawan mereka. Para menajer ini menyadari bahwa komitmen berhubungan langsung dengan peningkatan hasil kerja. Seperti yang dikemukakan oleh beberapa penelitian (Asbari \& Prasetya, 2021; Jumiran et al., 2020; Novitasari, Asbari, Hutagalung, et al., 2021; Nuryanti et al., 2020; Purwanto; et al., 2019; Sudiyono et al., 2020; Yuwono, Novitasari, Hutagalung, et al., 2020), bahwa komitmen organisasional dapat menjadi indikator nyata penilaian kinerja karyawan. Ketika karyawan sangat berkomitmen, mereka bekerja dan berkinerja jauh lebih baik. Mereka mencerminkan dedikasi dan loyalitas melalui kinerja kerja yang berbeda. Akibatnya, karyawan menunjukkan rasa hormat, baik niat sambil mematuhi instruksi manajer mereka, dan nilai-nilai organisasi dan kebijakan. Ketika karyawan sangat terikat pada organisasi, mereka berkorban untuk pertumbuhan perusahaan mereka. Bahkan mereka bisa berinvestasi secara suka rela untuk memperkuat afiliasi mereka dengan organisasi (Nuryanti et al., 2020). Oleh karena itu, mereka mencari teknik inovatif, dan bekerja lebih keras untuk membantu dalam pengembangan organisasi mereka. Dalam hal ini, komitmen karyawan merupakan faktor utama dibalik peningkatan kinerja dan daya saing organisasi. Jadi, hipotesis kedua dari studi ini adalah:

\section{H2: Komitmen kerja meningkatkan kinerja karyawan}

\section{Pengaruh Employee Coaching terhadap Employee Performance}

Menurut Sudiyono et al. (2020), dukungan manajemen merupakan sumber daya penting yang dapat digunakan karyawan untuk meningkatkan kinerjanya. Managerial coaching dapat dilihat sebagai bentuk dukungan sosial yang diberikan oleh manajemen perusahaan dalam informasi dan umpan balik terkait pekerjaannya. Manajemen perusahaan menggunakan proses umpan balik untuk mengungkapkan rasa terima kasih mereka kepada para karyawan atas upaya dan pencapaian mereka. Ketika karyawan merasa dihargai oleh perusahaan, maka memungkinkan mereka untuk mencurahkan lebih banyak energi dan waktu untuk meningkatkan kinerja mereka dan dengan demikian menguntungkan perusahaan (Asbari, 2019; Jumiran et al., 2020; Nuryanti et al., 2020; Suroso et al., 2021; Yuwono, Novitasari, Hutagalung, et al., 2020).

Berkenaan dengan hubungan antara managerial coaching dan hasil kerja, Ellinger et al. (2003) mempelajari dampak dari perilaku coaching pada kinerja dan kepuasan karyawan terhadap manajemen perusahaan. Hasil penelitian Ellinger et al. (2003) mengungkapkan bahwa manajemen perusahaan yang menggunakan perilaku coaching tidak hanya meningkatkan kepuasan kerja karyawan, tetapi juga meningkatkan tingkat komitmen kerja mereka dan pada akhirnya meningkatkan kinerja mereka dibandingkan dengan rekan-rekan mereka. Sebuah studi longitudinal oleh Liu \& Batt (2010) menemukan bahwa semakin banyak karyawan menerima managerial coaching yang efektif, maka semakin baik kinerja mereka, dan meningkat secara signifikan. Pousa \& Mathieu (2014) juga melakukan dua studi lapangan internasional, satu menggunakan tenaga penjual yang bekerja di Amerika Latin dan Kanada. Hasil empiris studi mereka menunjukkan bahwa coaching dapat meningkatkan kinerja karyawan. Selain itu, Hsu et al. (2019) meneliti pengaruh perilaku managerial coaching terhadap kinerja kerja dan peran komitmen organisasi dan kejelasan peran di antara 283 karyawan dari bank yang berbeda di Rawalpindi dan Islamabad. Hasil analisis regresi mereka mengungkapkan hubungan positif antara managerial coaching dan kejelasan peran, serta antara kinerja dan komitmen organisasi. Penelitian sebelumnya mendukung hubungan positif antara managerial coaching dan kinerja. Oleh karena itu, penelitian ini berupaya mengembangkan hipotesis berikut.

H3: Coaching meningkatkan kinerja karyawan.

\section{Efek Mediasi dari Komitmen Kerja}

Berkenaan dengan mekanisme yang menghubungkan coaching dengan kinerja karyawan, beberapa peneliti sebelumnya telah memberikan berbagai bukti empiris. Maamari et al. (2021) telah melakukan pengujian atas pengaruh managerial coaching terhadap komitmen kerja. Temuan mereka mengungkapkan bahwa komitmen kerja yang berkembang 
baik di tempat kerja secara signifikan memediasi hubungan antara managerial coaching dan kinerja. Studi tersebut di atas telah mengkonfirmasi adanya variabel mediator dalam hubungan antara coaching dan hasil kerja. Mengikuti alur pemikiran ini, penelitian ini menganggap komitmen kerja sebagai mediator potensial dan mengasumsikan bahwa managerial coaching secara tidak langsung mempengaruhi kinerja karyawan melalui komitmen kerja. Berdasarkan analisis tersebut, studi saat ini memprediksi bahwa manajemen perusahaan yang menunjukkan perilaku coaching yang efektif dapat meningkatkan komitmen kerja, yang pada gilirannya meningkatkan kinerja karyawan. Oleh karena itu, hipotesis berikut dikembangkan.

H4: Komitmen kerja secara signifikan memediasi hubungan antara coaching dan kinerja.

Sebagai kesimpulan dari tinjauan literatur terkait di atas, berikut ini adalah konseptual kerangka kerja telah dikembangkan untuk penelitian ini (lihat Gambar 1) dan dilanjutkankan untuk pengujian hipotesis.

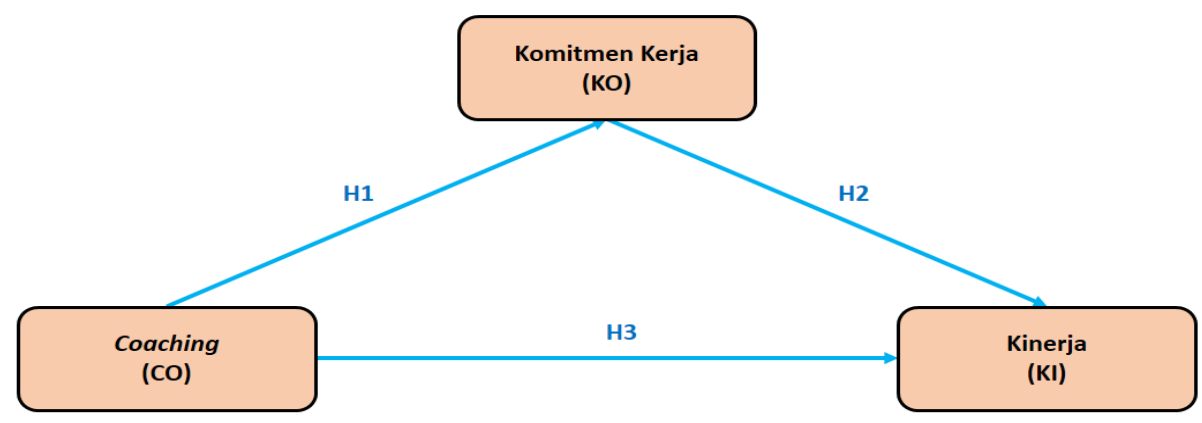

Gambar 1. Model Konseptual Penelitian

\section{METODE PENELITIAN}

Penelitian ini mengadopsi teknik survei dengan menggunakan analisis kuantitatif dan untuk mengumpulkan data tentang pengaruh coaching terhadap kinerja karyawan, baik secara langsung maupun tidak langsung melalui mediasi proses komitmen kerja. Survei memungkinkan para peneliti untuk mengumpulkan data dari karyawan yang berpartisipasi dalam sesi coaching yang dilakukan oleh atasan mereka, dan membantu mereka dalam menilai kinerja karyawan yang dirasakan. Teknik ini diadopsi karena kemampuannya untuk mengumpulkan data dengan cepat dibandingkan dengan alat lain, sementara memungkinkan pemilihan sampel secara acak, dan memungkinkan peneliti untuk mengukur dan mengontrol beberapa variabel. Setelah itu, untuk mengidentifikasi temuan atau pola dalam sampel terkait, data yang terkumpul kemudian dianalisis secara mendalam. Tujuan dari penelitian ini adalah untuk mengumpulkan pengetahuan yang berguna secara maksimal untuk membentuk hipotesis yang valid, yang jauh dari masukan subjektif. Dengan demikian, teori positivis diadopsi dalam penelitian ini karena mengidentifikasi kesamaan yang terlihat melalui observasi dan investigasi kerja. Oleh karena itu, pendekatan deduktif diikuti, berusaha untuk mengusulkan dan menguji hipotesis untuk menyesuaikan teori yang ada.

Untuk kepentingan penelitian ini, kuesioner dirancang dalam beberapa bagian: Bagian pertama mencakup pertanyaan demografis di mana karyawan secara anonim nyatakan jenis kelamin, usia, pendidikan, dan masa kerja perusahaan. Bagian kedua mencakup enam pertanyaan yang menangkap sejauh mana coaching diterapkan di perusahaan. Item pengukuran (CO1-CO6) ini diambil dari Ye et al. (2016). Instrumen yang digunakan untuk mengukur komitmen kerja diadaptasi dari Bishop \& Scott (2000) dan telah divalidasi oleh Admiral et al. (2021) dengan menggunakan 6 item (KO1-KO6). Sedangkan instrumen yang digunakan untuk mengukur kinerja karyawan diadaptasi dari Kim et al. (2013) dengan menggunakan 5 item (KI1-KI5). Kuesioner dirancang sedemikian rupa untuk menargetkan karyawan di salah satu industri manufaktur di Jawa Barat. Untuk memastikan kecukupan alat penelitian sesuai konteks, peneliti meneruskan kuesioner kepada empat peneliti yang catatannya kemudian dimasukkan. Selanjutnya, kuesioner diujicobakan pada 30 karyawan. Uji coba menghasilkan perubahan 
beberapa kata dalam skala item kuesioner untuk pemahaman yang lebih baik. Proses pengambilan sampel probabilitas menggunakan daftar yang diterima dari perusahaan. Dari daftar tersebut, sampel acak digunakan untuk mengumpulkan data dari karyawan yang sebelumnya telah menjalani coaching. Para peneliti mengumpulkan data secara anonim sesuai dengan standar etika penelitian dan dapat menerima tingkat tanggapan yang cukup besar melalui komunikasi online.

\section{HASIL DAN PEMBAHASAN \\ Deskripsi Sampel}

Total ada 1019 karyawan yang berpartisipasi. Sebagaimana di sebutkan pada Tabel 1, mereka memiliki kelompok umur yang berbeda-beda, berkisar antara di bawah usia 29 tahun (25.61\%), 30-49 tahun $(56.33 \%)$, dan lebih dari usia 50 tahun (18.06\%). Masa kerja mereka juga beragam, $32.97 \%$ di antaranya di bawah 5 tahun, 53.97\% sudah bekerja antara 5-10 tahun, dan 13.06\% sisanya telah bekerja lebih dari 10 tahun. Pendidikan tertinggi responden adalah mayoritas setingkat SLTA (54.96\%), kemudian Sarjana (25.02\%) dan Diploma (D1/D2/D3) (20.02\%).

Table 1. Deskripsi Sampel

\begin{tabular}{llll}
\hline Kriteria & & Jml. & \% \\
\hline Usia & $<30$ thn. & 261 & $25.61 \%$ \\
& $30-49$ thn. & 574 & $56.33 \%$ \\
\multirow{3}{*}{ Masa kerja sebagai karyawan } & $>50$ thn. & 184 & $18.06 \%$ \\
& $<5$ thn. & 336 & $32.97 \%$ \\
& $5-10$ thn. & 550 & $53.97 \%$ \\
Ijazah tertinggi & $>10$ thn. & 133 & $13.06 \%$ \\
& Sarjana & 255 & $25.02 \%$ \\
& Diploma (D1/D2/D3) & 204 & $20.02 \%$ \\
& SLTA & 560 & $54.96 \%$ \\
\hline
\end{tabular}

Sumber: Data Diolah (2021)

\section{Hasil Uji Validitas dan Reliabilitas Indikator Penelitian}

Tahap pengujian model pengukuran meliputi pengujian validitas konvergen, validitas diskriminan. Sementara untuk menguji reliabilitas konstruk digunakan nilai cronbach's alpha dan composite reliability. Hasil analisis PLS dapat digunakan untuk menguji hipotesis penelitian jika seluruh indikator dalam model PLS telah memenuhi syarat validitas konvergen, validitas deskriminan dan uji reliabilitas.

\section{Pengujian Validitas Konvergen}

Uji validitas konvergen dilakukan dengan melihat nilai loading factor masing-masing indikator terhadap konstruknya. Pada sebagian besar referensi, bobot faktor sebesar 0.7 atau lebih dianggap memiliki validasi yang cukup kuat untuk menjelaskan konstruk laten (Chin, 1998; Ghozali, 2014; Hair et al., 2010). Pada penelitian ini batas minimal besarnya loading factor yang diterima adalah 0.7, dan dengan syarat nilai AVE setiap konstruk > 0.5 (Ghozali, 2014). Setelah melalui pengolahan SmartPLS 3.0, hasil memperlihatkan bahwa seluruh indikator telah memiliki nilai loading factor di atas 0.7 dan nilai AVE di atas 0.5. Model fit atau valid dari penelitian ini dapat dilihat pada Gambar 2. Jadi dengan demikian, validitas konvergen dari model penelitian ini sudah memenuhi syarat. Nilai loadings, cronbach's alpha, composite reliability dan AVE setiap konstruk selengkapnya dapat dilihat Tabel 2.

\section{Pengujian Validitas Deskriminan}

Discriminant validity dilakukan untuk memastikan bahwa setiap konsep dari masing-masing variabel laten berbeda dengan variabel laten lainnya. Model mempunyai discriminant validity yang baik jika nilai kuadrat AVE masing-masing konstruk eksogen (nilai pada diagonal) melebihi korelasi antara konstruk tersebut dengan konstruk lainnya (nilai di bawah diagonal) (Ghozali, 2014). Hasil pengujian discriminant validity adalah dengan menggunakan nilai kuadrat AVE, yakni dengan melihat FornellLarcker Criterion Value diperoleh sebagaimana ditunjukkan pada Tabel 3. Hasil uji validitas deskriminan pada tabel 3 di atas menunjukkan bahwa seluruh konstruk telah memiliki nilai akar kuadrat AVE di atas nilai korelasi dengan konstruk laten lainnya (melalui kriteria Fornell-Larcker), sehingga dapat disimpulkan bahwa model telah memenuhi validitas deskriminan (Fornell \& Larcker, 1981). 
Selanjutnya dilakukan evaluasi collinearity untuk mengetahui ada tidaknya masalah collinearity pada model. Untuk menemukan collinearity tersebut, diperlukan statistik collinearity VIF dari setiap konstruk. Jika VIF lebih dari 5, maka model memiliki collinearity (Hair et al., 2014). Seperti yang ditunjukkan pada Tabel 4, semua skor VIF kurang dari 5, yakni hasil dari model struktural collinearity mengungkapkan nilai VIF di bawah 2. Hal ini menunjukkan bahwa model penelitian ini tidak ada masalah multikolinearitas.

\section{Pengujian Reliabilitas Konstruk}

Reliabilitas konstruk dapat dinilai dari nilai cronbach's alpha dan composite reliability dari masing-masing konstruk. Nilai composite reliability dan cronbach's alpha yang disarankan adalah lebih dari 0.7 (Ghozali, 2014). Hasil uji reliabilitas pada tabel 2 di atas menunjukkan bahwa seluruh konstruk telah memiliki nilai composite reliability dan cronbach's alpha lebih besar dari 0.7 (> 0.7$)$. Kesimpulannya, seluruh konstruk telah memenuhi reliabilitas yang dipersyaratkan.

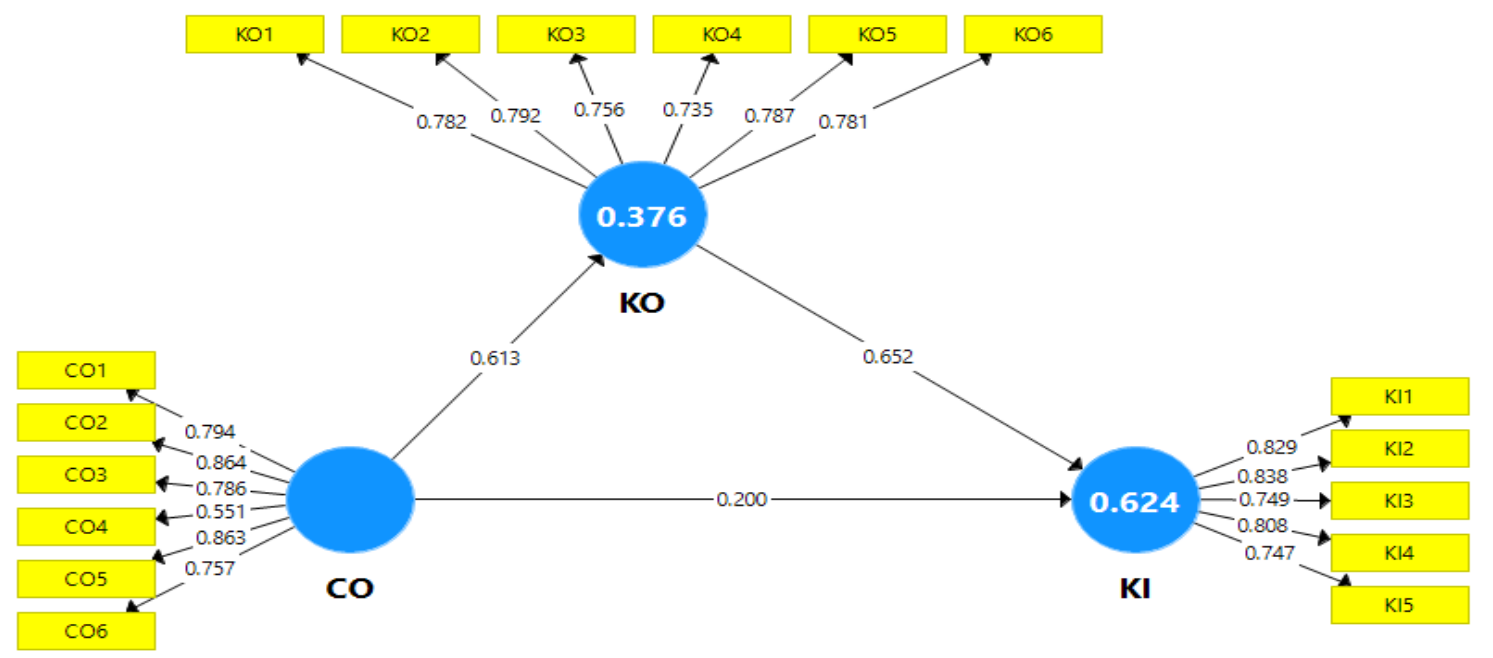

Gambar 2. Model Penelitian Valid

Sumber: Hasil Pengolahan SmartPLS 3.0 (2021)

Tabel 2. Items Loadings, Cronbach's Alpha, Composite Reliability, and Average Variance Extracted $(A V E)$

\begin{tabular}{|c|c|c|c|c|c|}
\hline Variables & Items & Loadings & $\begin{array}{l}\text { Cronbach's } \\
\text { Alpha }\end{array}$ & $\begin{array}{l}\text { Composite } \\
\text { Reliability }\end{array}$ & AVE \\
\hline \multirow[t]{6}{*}{ Coaching (CO) } & $\mathrm{CO} 1$ & 0.794 & 0.863 & 0.899 & 0.603 \\
\hline & $\mathrm{CO} 2$ & 0.864 & & & \\
\hline & $\mathrm{CO} 3$ & 0.786 & & & \\
\hline & $\mathrm{CO} 4$ & 0.551 & & & \\
\hline & CO5 & 0.863 & & & \\
\hline & CO6 & 0.757 & & & \\
\hline \multirow[t]{6}{*}{ Komitmen Kerja (KO) } & KO1 & 0.782 & 0.865 & 0.899 & 0.597 \\
\hline & $\mathrm{KO} 2$ & 0.792 & & & \\
\hline & KO3 & 0.756 & & & \\
\hline & KO4 & 0.735 & & & \\
\hline & $\mathrm{KO} 5$ & 0.787 & & & \\
\hline & KO6 & 0.781 & & & \\
\hline \multirow{5}{*}{ Kinerja (KI) } & KI1 & 0.829 & 0.854 & 0.896 & 0.632 \\
\hline & KI2 & 0.838 & & & \\
\hline & KI3 & 0.749 & & & \\
\hline & KI4 & 0.808 & & & \\
\hline & KI5 & 0.747 & & & \\
\hline
\end{tabular}

Sumber: Hasil Pengolahan SmartPLS 3.0 (2021) 
Tabel 3. Discriminant Validity

\begin{tabular}{lccc}
\hline Variables & CO & KI & KO \\
\hline Coaching (CO) & 0.776 & & \\
Kinerja (KI) & 0.600 & 0.795 & \\
Komitmen Kerja (KO) & 0.613 & 0.774 & 0.773 \\
\hline Sumber: Hasi Pengothen SmartPLS 3.0 (2021)
\end{tabular}

Sumber: Hasil Pengolahan SmartPLS 3.0 (2021)

Tabel 4. Collinearity (VIF)

\begin{tabular}{lccc}
\hline Variables & CO & KI & KO \\
\hline $\begin{array}{l}\text { Coaching (CO) } \\
\text { Kinerja (KI) }\end{array}$ & 1.603 & 1.000 \\
Komitmen Kerja (KO) & & 1.603 & \\
\hline
\end{tabular}

Sumber: Hasil Pengolahan SmartPLS 3.0 (2021)

Tabel 5. Nilai $R$ Square

\begin{tabular}{lcc}
\hline Variables & R Square & $\begin{array}{c}\text { R Square } \\
\text { Adjusted }\end{array}$ \\
\hline Kinerja (KI) & 0.624 & 0.624 \\
Komitmen Kerja (KO) & 0.376 & 0.376
\end{tabular}

Sumber: Hasil Pengolahan SmartPLS 3.0 (2021)

Tabel 6. Hypotheses Testing

\begin{tabular}{clccrrc}
\hline Hypotheses & \multicolumn{1}{c}{ Relationship } & Beta & SE & T Statistics & P-Values & Decision \\
\hline H1 & CO -> KO & 0.613 & 0.025 & 24.582 & 0.000 & Didukung \\
H2 & KO -> KI & 0.652 & 0.023 & 28.075 & 0.000 & Didukung \\
H3 & CO -> KI & 0.200 & 0.026 & 7.622 & 0.000 & Didukung \\
H4 & CO -> KO -> KI & 0.400 & 0.025 & 16.167 & 0.000 & Didukung \\
\hline
\end{tabular}

Sumber: Hasil Pengolahan SmartPLS 3.0 (2021)

\section{Pengujian Hipotesis}

Pengujian hipotesis dalam PLS disebut juga sebagai uji inner model. Uji ini meliputi uji signifikansi pengaruh langsung dan tidak langsung serta pengukuran besarnya pengaruh variabel eksogen terhadap variabel endogen. Untuk mengetahui pengaruh coaching terhadap kinerja karyawan melalui komitmen kerja sebagai variable mediasi dibutuhkan uji pengaruh langsung dan tidak langsung. Uji pengaruh dilakukan dengan menggunakan uji t-statistik dalam model analisis partial least squared (PLS) dengan menggunakan bantuan software SmartPLS 3.0. Dengan teknik boothstrapping, diperoleh nilai $R$ Square dan nilai uji signifikansi sebagaimana Tabel 5 dan Tabel 6.

Berdasarkan Tabel 5 di atas, nilai $R$ Square komitmen kerja (KO) sebesar 0.376 yang berarti bahwa variable komitmen kerja $(\mathrm{KO})$ mampu dijelaskan oleh variabel employee coaching $(\mathrm{CO})$ sebesar $37.6 \%$, sedangkan sisanya sebesar $62.4 \%$ dijelaskan oleh variabel lain yang tidak dibahas dalam penelitian ini. Sementara itu, nilai $R$ Square kinerja karyawan (KI) sebesar 0.624 yang berarti bahwa variabel kinerja karyawan (KI) mampu dijelaskan oleh variabel coaching $(\mathrm{CO})$ dan variabel komitmen kerja (KO) sebesar 62.4\%, sedangkan sisanya sebesar 37.6\% dijelaskan oleh variabel lain yang tidak dibahas dalam penelitian ini. Artinya bahwa substansi pengaruh dalam model hubungan pada model penelitian ini adalah terbilang kuat (Chin, 1998). Sedangkan Tabel 6 menampilkan $t$-statistics dan $p$ values yang menunjukkan pengaruh antar variable penelitian yang telah disebutkan. 


\section{PEMBAHASAN}

Menurut organization support theory (OST) (Eisenberger et al., 2016), ketika karyawan percaya bahwa organisasi menghargai kontribusi mereka dan peduli dengan kesejahteraan mereka, maka akan terjadi timbal balik, yakni membangkitkan rasa kewajiban karyawan untuk memberi kembali organisasi dengan meningkatkan komitmen dan kinerja. Atas dasar organization support theory, studi ini mengasumsikan bahwa ketika karyawan merasa bahwa manajemen industri manufaktur mereka menunjukkan perilaku coaching yang efektif, seperti mengkomunikasikan dan menetapkan ekspektasi yang jelas, menciptakan dan mempromosikan lingkungan belajar yang mendukung, dan menyediakan sumber daya, makahal itu akan menuntun mereka untuk meningkatkan kinerja mereka. Hasil penelitian ini menunjukkan bahwa coaching berdampak positif terhadap kinerja, temuan yang sejalan dengan penelitian sebelumnya (Akhtar \& Zia-ur-Rehman, 2017). Selain itu, penelitian ini memprediksi bahwa ada hubungan positif antara coaching dan komitmen kerja. Hamlin et al. (2009) menyatakan bahwa coaching adalah praktik membantu dan memandu karyawan, kelompok, dan organisasi untuk mendapatkan keahlian, kinerja, dan kemampuan baru serta mendorong peningkatan, efisiensi, dan pertumbuhan pribadi mereka. Meskipun potensi pengaruh coaching terhadap komitmen kerja belum banyak dieksplorasi oleh peneliti sebelumnya, hasil penelitian ini telah secara empiris mengkonfirmasi dan mendukung hipotesis bahwa coaching dapat meningkatkan aspek managerial commitment, systems perspectives, openness and experimentation, serta knowledge transfer and integration, yang merupakan indikator-indikator komitmen kerja. Lebih lanjut, menurut teori konservasi sumber daya dari Hobfoll (1989), komitmen kerja dapat dipandang sebagai sumber daya individu. Karyawan dengan komitmen kerja positif seringkali percaya bahwa mereka dapat melakukan pekerjaan mereka dengan baik dan mengharapkan hal-hal baik terjadi di tempat kerja (optimisme). Hasil penelitian ini menunjukkan bahwa komitmen kerja berpengaruh positif terhadap kinerja karyawan. Hasil studi ini sejalan dengan penelitian sebelumnya (Maamari et al., 2021) yang menunjukkan bahwa karyawan dengan komitmen kerja yang lebih tinggi akan menunjukkan kinerja yang lebih tinggi.

Penelitian sebelumnya telah menunjukkan bahwa komitmen kerja memainkan peran kunci dalam meningkatkan sikap dan perilaku kerja positif karyawan sebagai konsep penting dalam teori psikologi positif (Asbari \& Prasetya, 2021; Jumiran et al., 2020; Novitasari, Asbari, Hutagalung, et al., 2021; Nuryanti et al., 2020; Purwanto; et al., 2019; Sudiyono et al., 2020; Yuwono, Novitasari, Hutagalung, et al., 2020). Komitmen kerja juga ditemukan menjadi mediator penting dalam penelitian sebelumnya (Maamari et al., 2021). Hasil penelitian ini selaras dengan hipotesis penulis sebelumnya bahwa atasan yang menunjukkan perilaku coaching yang efektif dapat meningkatkan keadaan psikologis positif dari bawahan mereka (yaitu, efikasi diri, harapan, optimisme, dan ketahanan), yang selanjutnya dapat meningkatkan kinerja karyawan industri manufaktur (Grant et al., 2010; Park, 2007).

\section{KESIMPULAN}

Studi saat ini berkontribusi pada literatur coaching yang telah ada dengan mengeksplorasi efek dari praktik coaching pada kinerja karyawan dan dengan memeriksa efek mediasi dari komitmen kerja. Temuan penelitian ini mengkonfirmasi klaim penelitian sebelumnya. Misalnya, diklaim dalam literatur bahwa peningkatan kinerja hampir selalu diidentifikasi sebagai hasil potensial utama dari praktik coaching (Aldrin \& Utama, 2019; Ali et al., 2020; Kunst et al., 2018; Lee et al., 2019; Maamari et al., 2021). Jelas, hasil penelitian ini menunjukkan bahwa praktik coaching berpengaruh positif terhadap komitmen dan kinerja. Demikian pula, temuan penelitian ini menyatakan bahwa karyawan dapat mengembangkan kesadaran diri dengan umpan balik sistematis dari praktik coaching oleh pimpinan mereka dan umpan balik yang efektif ini dapat membantu karyawan memahami dengan jelas tujuan dan tanggung jawab mereka. Kesimpulannya, hasil penelitian ini menunjukkan bahwa coaching berpengaruh signifikan terhadap komitmen kerja dan kinerja karyawan, dan bahwa komitmen kerja memainkan peran mediasi yang signifikan dalam hubungan antara praktik coaching dan kinerja. 


\section{IMPLIKASI TEORITIS}

Berdasarkan analisis di atas, penelitian ini dengan jelas menunjukkan dampak coaching terhadap kinerja dan hasil positifnya. Ini juga menyoroti perubahan internal karyawan yang dihasilkan dari coaching seperti komitmen kerja tim (komitmen kerja) dan selanjutnya efek dari semua perubahan perilaku dan kognitif internal pada kinerja. Komitmen kerja jelas didorong dalam perilaku karyawan sebagai hasil dari pelaksanaan coaching. Ada korelasi yang jelas antara faktorfaktor tersebut dan menggunakan coaching sebagai praktik SDM yang efektif. Temuan ini menegaskan dan mengembangkan khasanah literatur mengenai efek coaching (Akhtar \& Zia-urRehman, 2017; Aldrin \& Utama, 2019; Hsu et al., 2019, 2019; Kunst et al., 2018; Raza et al., 2018). Pelajaran ini juga mengungkap beberapa aspek dari pengaruh konteks budaya, sosial dan ekonomi pada hubungan antara coaching dan kinerja yang absen dari tinjauan literatur.

Kontribusi inti dari penelitian ini adalah mengisi kesenjangan dalam teori tentang efek coaching pada kinerja terutama bahwa ada sangat sedikit organisasi industri manufaktur yang mempraktikkan dan mengevaluasi efek dari program coaching mereka pada kinerja karyawan atau karyawan mereka. Studi ini juga memiliki kontribusi penting yang menjelaskan faktor mediasi penting, yang hilang di sebagian besar studi, yang berurusan dengan coaching dan kinerja. Selain itu, studi ini telah berkontribusi pada teori dengan menambahkan literatur yang ada tentang beberapa wawasan tentang coaching yang merupakan alat pengembangan SDM di wilayah di mana studi tentang praktik SDM ini masih langka. Sedangkan ulasan komprehensif tentang program pengembangan SDM secara umum masih dalam masa pertumbuhan.

\section{IMPLIKASI MANAJERIAL}

Studi ini menegaskan bahwa program SDM yang mendukung, sebagaimana coaching memberikan manfaat yang lebih tinggi bagi organisasi industri manufaktur. Oleh karena itu, manajer SDM dihimbau untuk menerapkan kebijakan yang memungkinkan karyawan atau karyawan mereka untuk merasa aman dan dihargai. Karyawan perlu merasa sangat dihargai dan sehingga tidak mudah diganti, yang akibatnya mengurangi persaingan yang agresif di antara rekan kerja. Selain itu, prestasi dan promosi harus diberikan berdasarkan kompetensi masing-masing karyawan/karyawan dan tidak berdasarkan subyektivitas semata. Akibatnya, HRM harus berkomunikasi secara intensif dan bekerja untuk meningkatkan kesadaran karyawan/karyawan tentang pentingnya coaching dalam mendukung kemajuan dan perkembangan karir mereka. Melalui coaching, manajemen perusahaan membantu karyawan/karyawan fokus pada mengembangkan kemampuan-kemampuan yang akan memberikan kontribusi besar bagi individu dan keberhasilan organisasi perusahaan. Menerapkan coaching mengarah kepada peningkatan layanan pelanggan. Ini juga membantu peningkatan kinerja karyawan/karyawan, mengatasi tantangan, mencapai tujuan aspirasional dan membangun kepercayaan diri.

Dari perspektif penilaian kinerja, coaching membantu mengidentifikasi dan mengembangkan karyawan/karyawan berpotensi. Ini membantu mengidentifikasi kekuatan organisasi dan individu serta membuka peluang-peluang pengembangan. Studi ini memberikan alasan yang kuat terhadap perlunya praktik coaching dalam organisasi industri manufaktur yang menjamin efektivitas coaching manajerial sebagai prediktor kinerja karyawan/karyawan. Organisasi perusahaan perlu menekankan pada pentingnya coaching dan mendorong setiap unsur manajemen perusahaan untuk melatih bawahan mereka guna meningkatkan kinerja. Organisasi kemudian perlu menciptakan budaya coaching dan sistem pendukungnya, seperti usaha dan komitmen yang cukup besar dari manajemen. Coaching perlu menjadi bagian dari strategi pengembangan organisasi perusahaan. Oleh karena itu, diperlukan pelaksanaan secara rutin dengan keseriusan menindaklanjuti hasil-hasilnya.

Sebagaimana sebuah studi ilmiah, tentu penelitian ini masih terdapat kekurangan dan perlu ada perbaikan di masa mendatang. Oleh karena itu secara teoritis, saran penulis adalah: Sehubungan studi saat ini mengukur dan mengkaji kinerja karyawan sebagai hasil kerja dari praktik coaching. Peneliti berikutnya dapat menyelidiki dampak coaching pada hasil kerja penting lainnya, seperti kinerja dalam peran dan kontekstual, motivasi kerja, turnover intention, atau komitmen profesional/karier. 


\section{REFERENSI}

Admiral, Chidir, G., Asbari, M., Supriatna, H., \& Novitasari, D. (2021). Linking Employee Coaching, Team Commitment and Performance: Evidence from Indonesian MSMEs. International Journal of Social and Management Studies (IJOSMAS), 02(04), 22-34. https://www.ijosmas.org/index.php/ijosmas/article/view/48

Aguinis, H. (2019). Performance management for dummies. John Wiley \& Sons.

Akhtar, S., \& Zia-ur-Rehman, M. (2017). Impact of managerial coaching behavior on job performance: analyzing the role of organization commitment and role clarity. Journal of Managerial Sciences, $11(3), 298-318$.

Aldrin, N., \& Utama, A. P. (2019). Analysis of the effect of coaching on teamwork performance. International Journal of Research in Business and Social Science (2147-4478), 8(3), 24-32.

Ali, M., Raza, B., Ali, W., \& Imtaiz, N. (2020). Linking Managerial Coaching with Employees' Innovative Work Behaviors through Affective Supervisory Commitment: Evidence from Pakistan. International Review of Management and Marketing, 10(4), 11.

Asbari, M. (2019). Pengaruh kepemimpinan transformasional dan iklim organisasi terhadap kinerja dosen. JOCE IP, 13(2), 172-186. http://jurnal.ipem.ac.id/index.php/joce-ip/article/view/187

Asbari, M., Novitasari, D., \& Pebrina, E. T. (2021). Pengaruh Mediasi Mental Kesiapan untuk Berubah dan Work-Family Conflict terhadap Kinerja Karyawan di Masa Pandemi Covid-19. Mega Aktiva: Jurnal Ekonomi Dan Manajemen, 10(1), 24-38. https://megaaktiva.umkendari.ac.id/index.php/Jurnal/article/view/123

Asbari, M., \& Prasetya, A. B. (2021). Managerial Coaching: Rahasia Membangun Kinerja, Komitmen Tim dan Modal Psikologis Guru. Edumaspul - Jurnal Pendidikan, 5(1), 490-506. https://ummaspul.e-journal.id/maspuljr/article/view/1248

Asbari, M., Purba, J. T., Hariandja, E. S., \& Sudibjo, N. (2021a). From Leadership to Innovation: Managing Employee Creativity. Jurnal Manajemen Strategi Dan Aplikasi Bisnis, 4(1), 143-154. https://doi.org/https://doi.org/10.36407/jmsab.v4i1.287

Asbari, M., Purba, J. T., Hariandja, E. S., \& Sudibjo, N. (2021b). Membangun Kesiapan Berubah dan Kinerja Karyawan: Kepemimpinan Transformasional versus Transaksional. Jurnal Ilmiah Manajemen Dan Bisnis, 22(1), 54-71.

Asbari, M., Purwanto, A., \& Santoso, P. B. (2019). Influence of Leadership, Motivation, Competence, Commitment and Culture on ISO 9001:2015 Performance in Packaging Industry. Scholars Journal of Economics, Business and Management, 6(12), 577-582. https://doi.org/10.36347/sjebm.2019.v06i12.005

Bishop, J. W., \& Scott, K. D. (2000). An examination of organizational and team commitment in a selfdirected team environment. Journal of Applied Psychology, 85(3), 439-450. https://doi.org/10.1037/0021-9010.85.3.439

Cahyono, Y., Novitasari, D., Sihotang, M., Aman, M., Fahlevi, M., Nadeak, M., Siahaan, M., Asbari, M., \& Purwanto, A. (2020). The Effect of Transformational Leadership Dimensions on Job Satisfaction and Organizational Commitment: Case Studies in Private University Lecturers. Solid State Technology, 63(1s), http://www.solidstatetechnology.us/index.php/JSST/article/view/707

Chidir, G., Fayzhall, M., Sopa, A., Mustikasiwi, A., Asbari, M., \& Purwanto, A. (2020). The Role of Organizational Commitment, Organizational Culture and Mediator Organizational Citizenship Behavior (OCB) on Employees 'Performance: Evidence from Indonesian Automotive Industry. International Journal of Control and Automation, 13(2), 615-633. http://sersc.org/journals/index.php/IJCA/article/view/11205

Chin, W. (1998). The Partial Least Squares Approach to Structural Equation Modeling (E. Modern Methods for Business Research, In: G. A. Marcoulides (ed.)). Lawrence Erlbaum Associates Publisher. 
Eisenberger, R., Malone, G. P., \& Presson, W. D. (2016). Optimizing Perceived Organizational Support to Enhance Employee Engagement. Society for Human Resource Management, 1-22. http://www.siop.org/SIOP-SHRM/SHRM-SIOP POS.pdf

Ellinger, A. D., Ellinger, A. E., \& Keller, S. B. (2003). Supervisory coaching behavior, employee satisfaction, and warehouse employee performance: A dyadic perspective in the distribution industry. Human Resource Development Quarterly, 14(4), 435-458.

Fikri, M. A. A., Pramono, T., Nugroho, Y. A., Novitasari, D., \& Asbari, M. (2021). Leadership Model in Pesantren: Managing Knowledge Sharing through Psychological Climate. International Journal of Social and Management Studies (IJOSMAS), 02(03), 149-160. https://ijosmas.org/index.php/ijosmas/article/view/44

Fornell, C., \& Larcker, D. F. (1981). Evaluating Structural Equation Models with Unobservable Variables and Measurement Error. Journal of Marketing Research, 18(1), 39. https://doi.org/10.2307/3151312

Ghozali, I. (2014). Structural Equation Modeling, Metode Alternatif dengan Partial Least Square (PLS) (4th ed.). Badan Penerbit Universitas Diponegoro.

Grant, A. M., Green, L. S., \& Rynsaardt, J. (2010). Developmental coaching for high school teachers: Executive coaching goes to school. Consulting Psychology Journal, 62(3), 151-168. https://doi.org/10.1037/a0019212

Grover, S., \& Furnham, A. (2016). Coaching as a developmental intervention in organisations: A systematic review of its effectiveness and the mechanisms underlying it. PloS One, 11(7), e0159137.

Hair, J. F., Black, W. C., Babin, B. J., \& Anderson, R. E. (2010). Multivariate Data Analysis (7th ed.). Pearson Prentice Hall.

Hamlin, R. G., Ellinger, A. D., \& Beattie, R. S. (2009). Toward a Profession of Coaching ? A Definitional Examination of ' Coaching,' ' Organization Development,' and 'Human Resource Development. International Journal of Evidence Based Coaching and Mentoring, 7(1), 13-38.

Hobfoll, S. E. (1989). Conservation of resources: a new attempt at conceptualizing stress. American Psychologist, 44(3), 513.

Hsu, Y.-P., Chun-Yang, P., Pi-Hui, T., \& Ching-Wei, T. (2019). Managerial coaching, job performance, and team commitment: the meditating effect of psychological capital. Advances in Management and Applied Economics, 9(5), 101-125.

Hunt, J. M., \& Weintraub, J. R. (2016). The coaching manager: Developing top talent in business. SAGE publications.

Hutagalung, D., Admiral, Nuryanti, Y., Asbari, M., \& Novitasari, D. (2021). Managing Tacit Knowledge Sharing: From Charismatic Leadership to Psychological Safety Climate. Inovbiz: Jurnal Inovasi Bisnis, 9(1), 108-119. https://doi.org/10.35314/inovbiz.v9i1.1888

Imelda, D., Asbari, M., Purwanto, A., Sestri Goestjahjanti, F., \& Mustikasiwi, A. (2020). The Effect of Fairness of Performance Appraisal, Job Satisfaction and Commitment on Employees' Performance: Evidence from Indonesian Automotive Industry. International Journal of Advanced Science and Technology, 29(4),

2383-2396. https://doi.org/http://sersc.org/journals/index.php/IJAST/article/view/20519

Jumiran, Novitasari, D., Nugroho, Y. A., Sutardi, D., Sasono, I., \& Asbari, M. (2020). Pengaruh Dimensi Kepemimpinan Transformasional terhadap Kepuasan Kerja dan Komitmen Organisasional: Studi Kasus pada Dosen Perguruan Tinggi Swasta. EduPsyCouns: Journal of Education, Psychology and Counseling, 2(1), 600-621. https://ummaspul.ejournal.id/Edupsycouns/article/view/555

Kim, S., Egan, T. M., Kim, W., \& Kim, J. (2013). The impact of managerial coaching behavior on employee work-related reactions. Journal of Business and Psychology, 28(3), 315-330.

Kunst, E. M., van Woerkom, M., van Kollenburg, G. H., \& Poell, R. F. (2018). Stability and change in teachers' goal orientation profiles over time: Managerial coaching behavior as a predictor of profile change. Journal of Vocational Behavior, 104, 115-127. https://doi.org/10.1016/j.jvb.2017.10.003 
Kusumaningsih, S. W., Ong, F., Hutagalung, D., Basuki, S., Asbari, M., \& Purwanto, A. (2020). Organizational Culture, Organizational Commitment and Employees Performance: The Mediating Role of Organizational Citizenship Behavior. TEST Engineering and Management, 83(March-April 2020), http://www.testmagzine.biz/index.php/testmagzine/article/view/6958 $18277-18294$.

Lee, M. C. C., Idris, M. A., \& Tuckey, M. (2019). Supervisory coaching and performance feedback as mediators of the relationships between leadership styles, work engagement, and turnover intention. Human Resource Development International, 22(3), 257-282. https://doi.org/10.1080/13678868.2018.1530170

Liu, X., \& Batt, R. (2010). How supervisors influence performance: A multilevel study of coaching and group management in technology-mediated services. Personnel Psychology, 63(2), 265-298.

Maamari, B., El Achi, S., Yahiaoui, D., \& Nakhle, S. F. (2021). The effect of coaching on employees as mediated by organisational citizenship behaviour: case of Lebanon. EuroMed Journal of Business, January. https://doi.org/10.1108/EMJB-06-2020-0059

Novitasari, D., \& Asbari, M. (2021). Leaders Coaching di Sekolah: Apa Perannya terhadap Kinerja Guru? Edumaspul: Jurnal Pendidikan, 5(1), 580-597. https://ummaspul.ejournal.id/maspuljr/article/view/1299

Novitasari, D., Asbari, M., Hutagalung, D., \& Amri, L. H. A. (2021). Mengelola Komitmen Dosen: Analisis Peran Modal Psikologis dan Leaders Coaching. Value : Jurnal Manajemen Dan Akuntansi, 16(1), 198-213. https://e-journal.umc.ac.id/index.php/VL/article/view/1845

Novitasari, D., Asbari, M., Putra, F., Kumoro, D. F. C., \& Fikri, M. A. A. (2021). Tacit Knowledge Sharing di Sekolah Islam: Analisis Kepemimpinan dan Iklim Keamanan Psikologis. Cetta: Jurnal Ilmu Pendidikan, 4(2), 138-162. http://jayapanguspress.penerbit.org/index.php/cetta/article/view/1287

Novitasari, D., Asbari, M., Wijaya, M. R., \& Yuwono, T. (2020). Effect of Organizational Justice on Organizational Commitment: Mediating Role of Intrinsic and Extrinsic Satisfaction. International Journal of Science and Management Studies (IJSMS), 3(3), 96-112. http://www.ijsmsjournal.org/volume3-issue3.html

Novitasari, D., Hutagalung, D., Amri, L. H. A., Nadeak, M., \& Asbari, M. (2021). Kinerja Inovasi di Era Revolusi Industri 4.0: Analisis Knowledge-Oriented Leadership dan Kapabilitas Manajemen Pengetahuan. Edukatif: Jurnal Ilmu Pendidikan, 3(4), 1245-1260. https://doi.org/https://doi.org/10.31004/edukatif.v3i4.520

Novitasari, D., Hutagalung, D., Silitonga, N., Johan, M., \& Asbari, M. (2021). Membangun Perencanaan dan Kinerja Tim: Analisis Pengaruh Efikasi Kolektif dan Iklim Kecerdasan Emosional. JKBM (Jurnal Konsep Bisnis Dan Manajemen), 7(2), 191-205. https://doi.org/10.31289/jkbm.v7i2.5116

Novitasari, D., Supiana, N., Supriatna, H., Fikri, M. A. A., \& Asbari, M. (2021). The Role of Leadership on Innovation Performance: Transactional versus Transformational Style. JIMFE (Jurnal Ilmiah $\begin{array}{llll}\text { Manajemen } \quad \text { Fakultas } & \text { Ekonomi), } & \text { 7(1), }\end{array}$ https://journal.unpak.ac.id/index.php/jimfe/article/view/2981

Nuryanti, Y., Novitasari, D., Nugroho, Y. A., Fauji, A., Gazali, \& Asbari, M. (2020). Meningkatkan Komitmen Organisasional Dosen: Analisis Pengaruh Kepemimpinan Perguruan Tinggi dan Kepuasan Intrinsik \& Ekstrinsik Dosen. EduPsyCouns: Journal of Education, Psychology and Counseling, 2(1), 561-581. https://ummaspul.e-journal.id/Edupsycouns/article/view/551

Park, S. (2007). Relationships among managerial coaching in organizations and the outcomes of personal learning, organizational commitment, and turnover intention. University of Minnesota.

Pousa, C., \& Mathieu, A. (2014). Boosting customer orientation through coaching: a Canadian study. International Journal of Bank Marketing. 
Pramono, T., Asbari, M., Supriatna, H., Nugroho, Y. A., \& Novitasari, D. (2021). Rahasia Inovasi Karyawan Wanita di Era Digital: Analisis Modal Psikologis dan Dukungan Kepemimpinan. Value: Jurnal Manajemen Dan Akuntansi, 16 (2), 1-17. $\mathrm{https://e}$ journal.umc.ac.id/index.php/VL/article/view/1924

Purwanto;, A., Asbari;, M., \& Santoso, P. B. (2019). Pengaruh Kompetensi, Motivasi, Kepemimpinan, Komitmen dan Budaya Kerja Sistem Manajemen Integrasi ISO 9001, ISO 14000 dan ISO 45001 pada Industri Otomotif. Jurnal Produktivitas, 6(2), 158-166. http://openjurnal.unmuhpnk.ac.id/index.php/jp/article/view/1798

Purwanto, A., Hidayat, D., \& Asbari, M. (2021). Work-Family Conflict Disaster: From Organizational Commitment to Job Satisfaction. International Journal of Social and Management Studies (IJOSMAS), 02(01), 86-92. https://doi.org/https://doi.org/10.5555/ijosmas.v2i1.13

Raza, B., Ali, M., Ahmed, S., \& Ahmad, J. (2018). Impact of managerial coaching on organizational citizenship behavior: The mediation and moderation model. International Journal of Organizational Leadership, 7, 27-46.

Sidhu, G. K., \& Nizam, I. (2020). Coaching and Employee Performance: The Mediating Effect of Rewards \& Recognition in Malaysian Corporate Context. International Journal of Management, Accounting and Economics, 7(1), 41-72.

Silitonga, N., Novitasari, D., Sutardi, D., Sopa, A., Asbari, M., Yulia, Y., Supono, J., \& Fauji, A. (2020). The Relationship of Transformational Leadership, Organizational Justice and Organizational Commitment: a Mediation Effect of Job Satisfaction. Journal of Critical Reviews, 7(19), 89-108. http://www.jcreview.com/?mno=101999

Sudiyono, R. N., Goestjahjanti, F. S., Asbari, M., Fayzhall, M., Yani, A., Winanti, Yuwono, T., Nurasiah, Yulia, Y., Singgih, E., \& Chidir, G. (2020). Meningkatkan Komitmen dan Kinerja Dosen: Apa Peran Manajemen Perguruan Tinggi? EduPsyCouns: Journal of Education, Psychology and Counseling, 2(1), 337-352. https://ummaspul.ejournal.id/Edupsycouns/article/view/489/283

Suroso, Riyanto, Novitasari, D., Sasono, I., \& Asbari, M. (2021). Esensi Modal Psikologis Dosen: Rahasia Kreativitas dan Inovasi di Era Education 4.0. Edumaspul - Jurnal Pendidikan, 5(1), 437451. https://ummaspul.e-journal.id/maspuljr/article/view/1240

Szabó, S., Slavić, A., \& Berber, N. (2019). Coaching and its effects on individual and organizational performances in Central and Eastern Europe. Anali Ekonomskog Fakulteta u Subotici, 55(41), 6780. https://doi.org/10.5937/aneksub1941067s

Ye, R. (Michelle), Wang, X. H. (Frank), Wendt, J. H., Wu, J., \& Euwema, M. C. (2016). Gender and managerial coaching across cultures: female managers are coaching more. International Journal of Human Resource Management, 27(16), 1791-1812. https://doi.org/10.1080/09585192.2015.1075570

Yuwono, T., Novitasari, D., Asbari, M., Sutardi, D., Mustofa, \& Asbari, M. (2020). Peran Organizational Commitment terhadap Hubungan Work- Family Conflict dan Kepuasan Kerja Karyawan Wanita di Kota Seribu Industri Tangerang. EduPsyCouns: Journal of Education, Psychology and Counseling, 2(1), 524-540. https://ummaspul.ejournal.id/Edupsycouns/article/view/526/303

Yuwono, T., Novitasari, D., Hutagalung, D., Sasono, I., Silitonga, N., \& Asbari, M. (2020). Peran Organizational Justice terhadap Komitmen Organisasional: Analisis Mediasi Kepuasan Kerja Dosen Perguruan Tinggi Swasta. EduPsyCouns: Journal of Education, Psychology and Counseling, 2(1), 582-599. https://ummaspul.e-journal.id/Edupsycouns/article/view/550 